\title{
Distribution and redox speciation of dissolved iron on the European continental margin
}

Simon J. Ussher and Paul J. Worsfold

School of Earth, Ocean and Environmental Sciences (SEOES), University of Plymouth, Drake Circus, Plymouth, PL4 8AA, United Kingdom

Eric P. Achterberg

National Oceanography Centre, University of Southampton, European Way, Southampton, SO14 3ZH, United Kingdom

Agathe Laës

Département Technologie des systèmes instrumentaux (TSI), Institut français de recherche pour l'exploitation de la mer (IFREMER), Centre de Brest, BP 70, 29280 Plouzané, France

\section{Stéphane Blain}

Centre d'Océanologie de Marseille, Laboratoire d'Océanographíe et biogéochimie (LOB), Unité mixte de recherché (UMR), Centre national de la recherche scientifique (CNRS) 6535, Campus de Luminy, case 901, F-13288 Marseille Cedex, France

Patrick Laan and Hein J. W. de Baar

Royal Netherlands Institute for Sea Research (NIOZ), P.O. Box 59, NL-1790 AB Den Burg (Texel), The Netherlands

\begin{abstract}
To investigate the biogeochemistry of iron in the waters of the European continental margin, we determined the dissolved iron distribution and redox speciation in filtered $(<0.2 \mu \mathrm{m})$ open-ocean and shelf waters. Depth profiles were sampled over the shelf slope southeast of the Chapelle Bank area $\left(47.61^{\circ} \mathrm{N}, 4.24^{\circ} \mathrm{W}\right.$ to $46.00^{\circ} \mathrm{N}$, $8.01^{\circ} \mathrm{W}$ ) and a horizontal surface-water transect over the shelf and through the English Channel (la Manche) and the southern North Sea $\left(46^{\circ} \mathrm{N}, 8^{\circ} \mathrm{W}\right.$ to $\left.52^{\circ} \mathrm{N}, 4^{\circ} \mathrm{E}\right)$. An abrupt trace-metal front was found near the shelf slope, indicated by a horizontal gradient of dissolved iron (DFe) and aluminium (DAl), which correlated with changing salinities $\left(r^{2}=0.572\right.$ and 0.528 , respectively, $\left.n=92\right)$. Labile Fe(II) concentrations varied from $<12 \mathrm{pmol} \mathrm{L}^{-1}$ in North Atlantic surface waters to $>200 \mathrm{pmol} \mathrm{L}^{-1}$ in the near bottom waters of the shelf break. Labile Fe(II) accounted for $\sim 5 \%$ of the dissolved iron species in surface shelf waters (mean $5.0 \pm 2.7 \%$ ), whereas higher Fe(II) fractions (i.e., $>8 \%$ ) were observed near the sea bottom on the shelf break and during a midday solar maximum in surface waters in the vicinity of the Scheldt river plume. Benthic processes (resuspension and diagenesis) constituted important sources of Fe(II) and DFe in this region, and photoreduction of Fe(III) species in shelf waters caused enhanced labile $\mathrm{Fe}(\mathrm{II})$ concentrations. These processes increased the lability of iron and its potential availability to marine organisms in the shelf ecosystem.
\end{abstract}

The biogeochemistry of iron in the open ocean has received widespread attention in recent years due to its role in the biogeochemical control and feedback affecting ocean

\section{Acknowledgments}

We thank Andrew Fisher for the dissolved aluminium analyses, the technical support given by the Royal NIOZ, and the officers and crew of the RV Pelagia. Surface chlorophyll data were acquired from Goddard Earth Sciences (GES) Data and Information Services Center (DISC) Interactive Online Visualization and Analysis Infrastructure (Giovanni) as part of the National Aeronautics and Space Administration's GES Data and Information Services Center-DISC. The project was funded under the European Commission's Iron Resources and Oceanic Nutrients Advancement of Global Environment Simulations (IRONAGES) project (EVK2-CT1999-00031), and the Natural Environment Research Council provided time to complete this work under research grant NER/A/S/2003/00489. We thank the two reviewers for the constructive criticism that added to the quality of the paper. primary productivity (Falkowski et al. 1998). Evidence of basin-scale iron limitation has been observed in highnutrient, low-chlorophyll (HNLC) regions (Boyd et al. 2007). In the North Atlantic Ocean, reported surface-water dissolved iron (DFe) concentrations are in the range 0.02 $1.5 \mathrm{nmol} \mathrm{L}^{-1}$ (Sarthou et al. 2003). The apparent ironreplete conditions in the North Atlantic are caused by enhanced iron inputs from shelf waters and atmospheric dust deposition. Despite this, there is growing evidence that not all open-ocean biological ecosystems in the North Atlantic are iron replete all year-round. Iron co-limitation has been observed in temperate Atlantic regions (Moore et al. 2006). Therefore, microbial communities are dependent on the delivery of iron to the euphotic zone in the North Atlantic.

Elevated iron concentrations in shelf waters are a result of high iron inputs (e.g., rivers, sediment resuspension, and diagenesis), and the transport of iron from shelf regions to the open ocean is evident from the existence of iron 
gradients that extend beyond a continental-shelf slope. These iron gradients have been reported from highresolution offshore surface transects in the northeast Pacific Ocean (e.g., Johnson et al. 2003). Furthermore, a recent study has shown that the HNLC region in the subarctic Pacific Ocean is enriched by particulate iron from the continental margin, over $1,000 \mathrm{~km}$ from the study area (Lam et al. 2006).

Based on benthic-chamber sampling, Elrod et al. (2004) calculated a lower limit for the global flux of dissolved iron

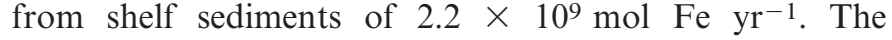
principal mechanism for elevated iron concentrations in pore waters is the reduction of solid-phase iron in shelf sediments during diagenesis. Retention of $\mathrm{DFe}$ in shelf waters is influenced by processes in the water column, such as biological recycling, particle adsorption, redox processes, and complexation by organic ligands. These processes are likely to alter the redox speciation of iron, either at the sediment/seawater interface, in the photic zone, or in suboxic/anoxic regions of the water column.

Iron redox speciation in seawater is controlled by several key variables. Typically, open-ocean waters are oxic, and, hence, dissolved oxygen and hydrogen peroxide concentrations are highly significant because they control the kinetics of $\mathrm{Fe}(\mathrm{II})$ oxidation and the electron activity of seawater. Furthermore, temperature alters Fe(II) oxidation rates (Millero et al. 1987) and could therefore cause latitudinal and vertical variation in iron redox speciation. In situ iron addition experiments have also demonstrated an apparent stabilization of $\mathrm{Fe}(\mathrm{II})$ by the reduction of $\mathrm{Fe}(\mathrm{III})$ with superoxide and/or organic complexation (Croot et al. 2005). Photoreduction of dissolved and colloidal iron has been extensively studied and shown to maintain significant pseudo-steady state $\mathrm{Fe}(\mathrm{II})$ concentrations in coastal waters (Miller et al. 1995).

Model equilibrium calculations indicate that inorganic $\mathrm{Fe}(\mathrm{II})$ species (including $\mathrm{Fe}^{2+}, \mathrm{FeCO}_{3}^{0}$, and $\mathrm{FeCl}^{+}$) exist at negligible concentrations $\left(<1 \times 10^{-12} \mathrm{~mol} \mathrm{~L}^{-1}\right)$ in oxygenated seawater compared with Fe(III) species (Waite 2001). However, $>95 \%$ of $\mathrm{DFe}$ is reported to be organically complexed in seawater (e.g., Van Den Berg 1995). Inorganic and organic iron-binding ligands in seawater remain uncharacterized but have important implications for iron redox chemistry, as complexation can alter the free energy of $\mathrm{Fe}(\mathrm{II})$ : $\mathrm{Fe}(\mathrm{III})$ redox states (Dhungana and Crumbliss 2005) as well as $\mathrm{Fe}(\mathrm{II})$ oxidation rates (Santana-Casiano et al. 2006). Furthermore, Fe(III)-chelates can be an important source of kinetically labile $\mathrm{Fe}(\mathrm{II})^{\prime}$ and are more prone to direct and indirect photochemical reduction than inorganic moieties (Ozturk et al. 2004).

The production of $\mathrm{Fe}(\mathrm{II})$ in seawater via photoreduction and abiotic redox reactions within the water column can also recycle dissolved and refractory iron species. In addition, bacterial oxidation of organic matter can create micro- and macro-environments capable of reducing iron species, and biologically controlled redox cycling of iron complexes has also been observed for some marine eukaryotes (Maldonado et al. 2005). The effects of reduction mechanisms in shelf waters may be highly significant to primary productivity since kinetically labile

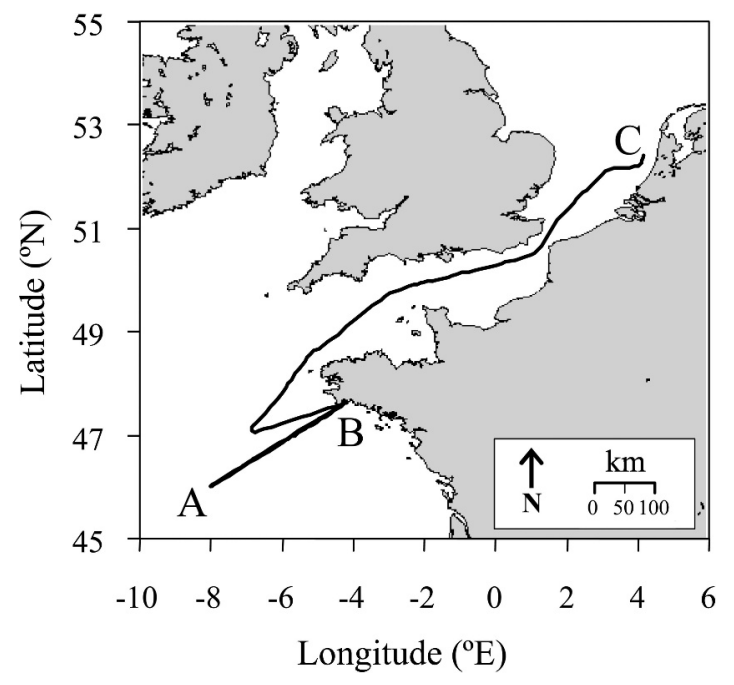

Fig 1. IRONAGES cruise track showing the vertical section (position A to B) and underway transect (position A to C) on the European continental shelf and slope (adapted from online map creation, http://www.aquarius.ifm-geomar.de).

inorganic $\mathrm{Fe}(\mathrm{II})^{\prime}$ and $\mathrm{Fe}(\mathrm{III})^{\prime}$ species are accessible forms of iron to eukaryotes (Hudson and Morel 1990). However, our knowledge of the behavior of $\mathrm{Fe}(\mathrm{II})$ in oceanic waters is poor, and there is little evidence that water-column processes control bulk steady state $\mathrm{Fe}$ (II) concentrations. The paucity of redox speciation data for open-ocean regions has been mainly due to a lack of suitable analytical techniques. However, the emergence of flow-injection chemiluminescence methods (Bowie et al. 2002; Croot and Laan 2002) capable of rapid analysis and picomolar detection limits has made investigations into oceanic iron redox processes possible.

In this study, the aim was to assess the influence of the European continental margin on the dissolved iron distribution and speciation in overlying waters during the IRONAGES programme (Iron Resources and Oceanic Nutrients-Advancement of Global Environment Simulations). The distribution of labile Fe(II) and DFe concentrations are reported for waters southeast of the Chapelle Bank area $\left(47.61^{\circ} \mathrm{N}, 4.24^{\circ} \mathrm{W}\right.$ to $\left.46.00^{\circ} \mathrm{N}, 8.01^{\circ} \mathrm{W}\right)$ and for the shelf waters of the English Channel (la Manche) and the southern North Sea $\left(46^{\circ} \mathrm{N}, 8^{\circ} \mathrm{W}\right.$ to $\left.52^{\circ} \mathrm{N}, 4^{\circ} \mathrm{E}\right)$ during spring 2002, along with dissolved aluminium (DAl) surfacewater concentrations. These data are discussed in terms of potential benthic sources, water mass mixing, and photochemical processes that affect the concentration and speciation of dissolved iron in this region.

\section{Materials and methods}

Cruise location - Sampling and shipboard measurements were made on the RV Pelagia from the 11 March 2002 to 03 April 2002. Sampling of the water column was conducted at the start of the spring bloom period, over a transect horizontally perpendicular to the contours of the European continental-margin slope near the Chapelle Bank region (Fig. 1). This area is characterized by a broad 
continental shelf with a steep slope that extends down to $\sim 4,500 \mathrm{~m}$. The residual flow of surface shelf waters in the English Channel is predominantly eastward and highest in the winter. The major water mass transport in subsurface waters at the shelf break is caused by a northward slope current, which flows at a velocities of $\sim 100-300 \mathrm{~cm} \mathrm{~s}^{-1}$ and tides that cause strong internal waves at the shelf break (Huthnance et al. 2001). Storm conditions were prevalent during the first two weeks of the cruise (wind speed $>15 \mathrm{~m}$ $\mathrm{s}^{-1}$ ), which were typical for this time of year.

Vertical profiles were sampled at 15 stations positioned along a transect line that extended into the Bay of Biscay between $47.61^{\circ} \mathrm{N}, 4.24^{\circ} \mathrm{W}$ and $46.00^{\circ} \mathrm{N}, 8.01^{\circ} \mathrm{W}$ (positions $\mathrm{A}$ and B, Fig. 1). Hourly discrete and near real-time underway surface-water sampling was conducted between stations using a towed fish that was deployed $5 \mathrm{~m}$ from the starboard side of the ship. Following this, two further surface-water transects across the shelf slope were completed before sampling through the English Channel to the coast of the Netherlands (positions B to C, Fig. $1 ; 46^{\circ} \mathrm{N}$, $8^{\circ} \mathrm{W}$ to $\left.52^{\circ} \mathrm{N}, 4^{\circ} \mathrm{E}\right)$.

Sample processing - Cast samples for labile Fe(II), DFe, and DAl were taken from precleaned, Teflon ${ }^{\mathrm{TM}}$-coated GoFlo bottles (General Oceanics ${ }^{\mathrm{TM}}$ ), which were deployed on a Kevlar wire (De Jong et al. 1998). After recovery, the bottles were immediately mounted in a laminar-flow cabinet in a clean container. Surface-water sampling was conducted whilst the ship was steaming $\left(20-25 \mathrm{~km} \mathrm{~h}^{-1}\right)$ using a trace-metal-clean towed fish connected by polytetrafluoroethylene (PTFE) tubing to a PTFE bellows pump (Almatec ${ }^{\mathrm{TM}} \mathrm{A}-15$ ), which provided a flow rate of $\sim 3 \mathrm{~L} \mathrm{~min}^{-1}$ (Croot and Laan 2002). The pump was driven by a compressor (Jun-AirTM, model 600-4B) operating at a pressure of 150-200 $\mathrm{kPa}$. This underway pumping system supplied surface seawater directly into the clean container and ran continuously between stations. All sample handling was conducted using trace-metal protocols in a class 100 laminar flow hood inside the clean container.

Samples for $\mathrm{DFe}$ and DAl were filtered through Sartobran cartridges $(0.2-\mu \mathrm{m}$-pore size, cellulose acetate membrane, Sartorius ${ }^{\mathrm{TM}}$ ), either in-line from the surface pump supply or using a filtered nitrogen overpressure on the GoFlo bottles. Discrete cast samples for DFe were collected in 250-mL, acid-washed, low-density polyethylene (LDPE) bottles (Nalgene ${ }^{\mathrm{TM}}$ ), which were previously stored filled with acidified high-purity water $\left(18.2 \mathrm{M} \Omega \mathrm{cm}^{-1}\right.$, $\mathrm{Elga}^{\mathrm{TM}}, 0.01 \mathrm{~mol} \mathrm{~L}^{-1}$ quartz-distilled $\mathrm{HCl}$, VWR $\mathrm{TM}$ ). Cast sample filtration was completed within $1.5 \mathrm{~h}$ after collection, and the samples were then acidified $(\mathrm{pH} \mathrm{1.9,} \mathrm{quartz-}$ distilled $\mathrm{HCl}$ ) and stored for laboratory analysis.

Cast subsamples for labile $\mathrm{Fe}(\mathrm{II})$ were transferred into acid-washed and prerinsed PTFE vials in a laminar flow hood. The samples were then filtered immediately by pumping directly through a prewashed syringe filter (0.2$\mu \mathrm{m}$-pore size, PTFE membrane, GelmanTM) into a flow injection chemiluminescence (FI-CL) analyzer. This allowed measurements to be made within $20 \mathrm{~min}$ of sampling. The method used for surface waters was

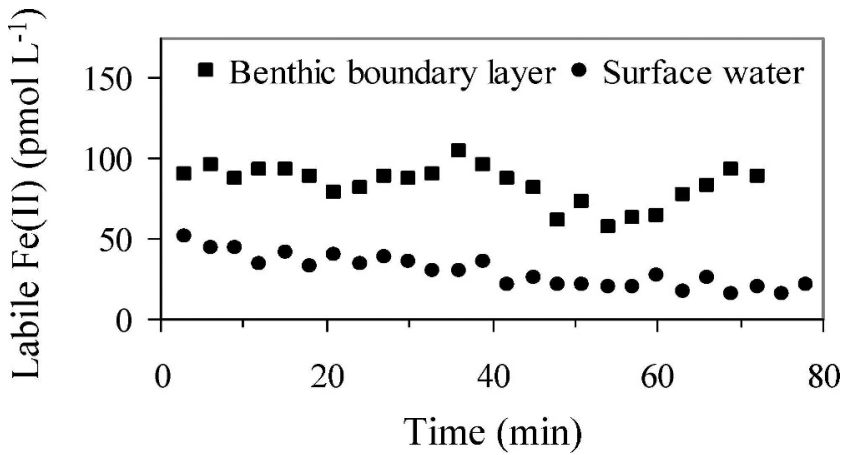

Fig 2. Stability of labile Fe(II) in GoFlo sample bottles containing shelf waters sampled in the benthic boundary layer $(80 \mathrm{~m})$ and surface $(20 \mathrm{~m})$.

identical, except that water was pumped directly from the towed fish through a $0.2-\mu$ m-pore-size syringe filter using a peristaltic pump (Minipuls 3, GilsonTM). The filter was coupled directly to the flow injection manifold, allowing measurements to be made $<6$ min after sampling.

Analytical methods - Labile Fe(II) was determined by inline solid phase preconcentration onto an 8-hydroxyquinoline resin at $\mathrm{pH} 5.0$ followed by acid elution and luminol chemiluminescence detection. The FI-CL method has previously been used for underway $\mathrm{Fe}$ (II) determination in the Southern Ocean and South Atlantic Ocean, and details of the method can be found elsewhere (Bowie et al. 2002). The limit of detection of this method (defined as three times the standard deviation of the blank) ranged from 5 to $12 \mathrm{pmol} \mathrm{L}^{-1}$. The measurement was termed "labile Fe(II)" because the exact speciation of the iron complexes is unknown, and the term Fe(II) may imply that only inorganic $\mathrm{Fe}(\mathrm{II})$ species were determined. The percentage of dissolved $\mathrm{Fe}(\mathrm{II})$ was calculated as the ratio of labile $\mathrm{Fe}(\mathrm{II})$ over the dissolved iron concentration, i.e., $(\mathrm{Fe}(\mathrm{II}): \mathrm{DFe}) \times 100 \%)$. The labile $\mathrm{Fe}(\mathrm{II})$ fraction was assessed for potential interferences by $100 \mathrm{nmol} \mathrm{L^{-1 }}$ additions of first-row transition metals in acidified and unacidified North Atlantic seawater. The results indicated no significant interference $(<1 \%$ relative $\mathrm{Fe}[\mathrm{II}]$ signal $)$ except for cobalt(II), which had a comparable sensitivity to

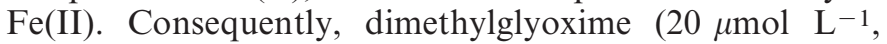
Sigma) was added to the luminol reagent. This masked cobalt(II) at concentrations $\leq 10 \mathrm{nmol} \mathrm{L} \mathrm{L}^{-1}$, which is at least an order of magnitude greater than would be found in most seawaters. A further study with organic ligands also showed that some complexes caused a slight positive interference $(<1 \%$ of total iron concentration; Ussher et al. 2005), but the concentrations used in the study $\left(100 \mathrm{nmol} \mathrm{L}{ }^{-1}\right)$ were assumed to be in excess of those of individual organic ligands in the ocean.

To assess the stability of $\mathrm{Fe}(\mathrm{II})$ in the samples, a GoFlo bottle was used to sample the benthic boundary layer $(80 \mathrm{~m})$ and surface waters $(20 \mathrm{~m}$, during the midday solar maximum) on the shelf. For both experiments, the sample bottles were immediately brought into the clean container, and a PTFE tube $(0.75-\mathrm{mm}$ internal diameter) was inserted into the spigot of the sampler. Labile Fe(II) was then 

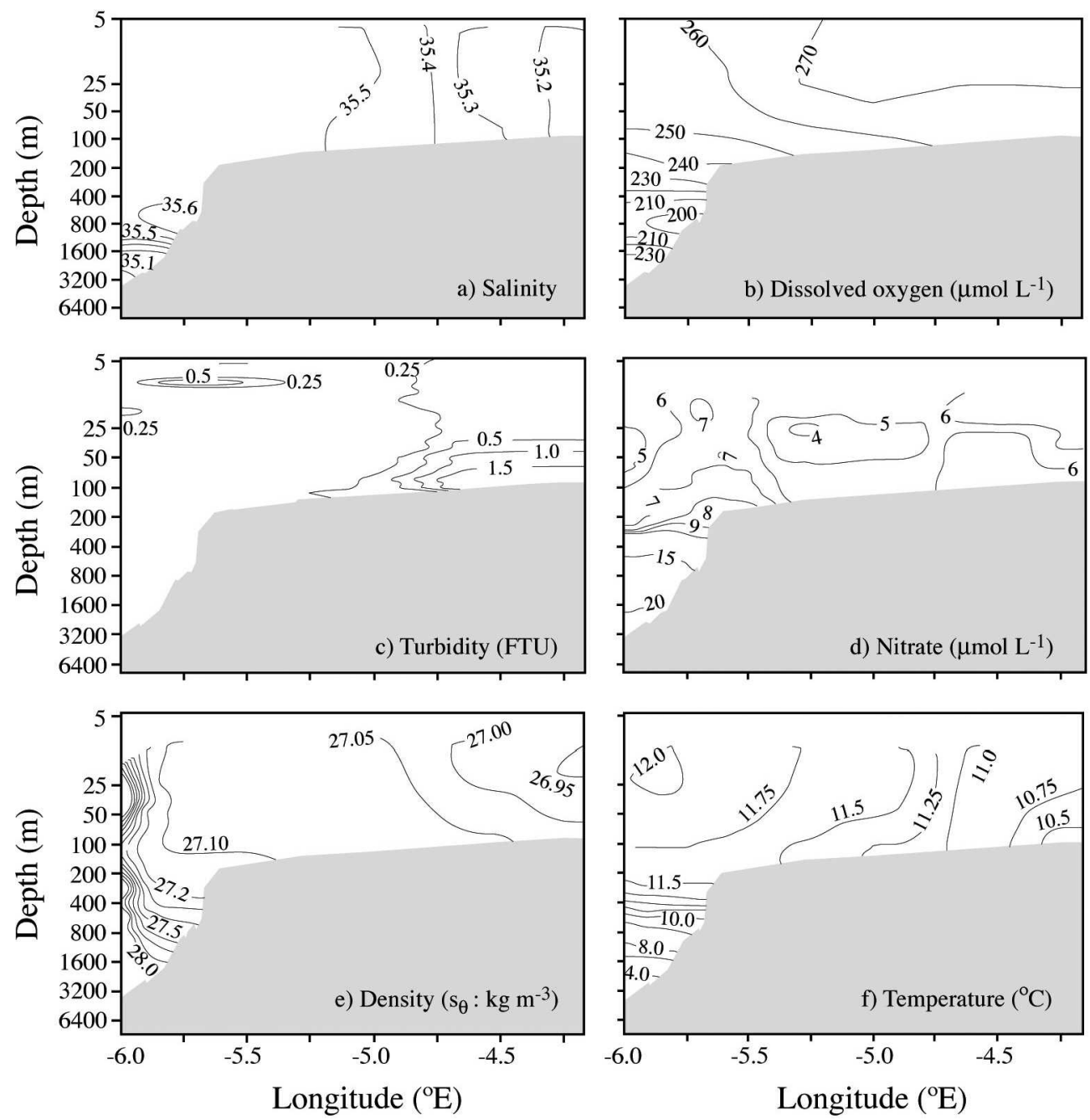

Fig 3. Physico-chemical variables over the European continental shelf and slope: (a) salinity, (b) dissolved oxygen, (c) turbidity, (d) nitrate concentrations, (e) density, and (f) temperature.

monitored over a period of $80 \mathrm{~min}$ (Fig. 2). The Fe(II) signal for the sample of the benthic boundary layer was found to remain stable throughout this time. Hence, the samples taken below $50 \mathrm{~m}$ were assumed to be stable within the 20-min sampling time employed. In contrast, the signal for the surface sample decreased with time; therefore, some loss of the $\mathrm{Fe}(\mathrm{II})$ signal was expected during the $6 \mathrm{~min}$ transit time of the surface water in the towed fish sampler to the FI-CL analyzer. However, considering the physicochemical diversity of shelf waters, the loss was not considered to be significant $(<10 \%)$ compared with the error that could be incurred by extrapolating determined labile $\mathrm{Fe}(\mathrm{II})$ concentrations to the time of sampling $(t=0)$.

DFe was determined using FI-CL in a shore-based class 1,000 clean room after a 4-month sample acidification period and a $12 \mathrm{~h}$ sulfite reduction step (Bowie et al. 1998). All measurements reported for both the $\mathrm{Fe}(\mathrm{II})$ and $\mathrm{DFe}$ methods were the mean values of three or four replicates (where peak height was measured). The DFe analytical method was validated by triplicate analyses of the IRONAGES reference standard (bottle number 233; Bowie et al. 2006). The result was $0.55 \pm 0.06 \mathrm{nmol} \mathrm{L}^{-1}$, which compared well with the mean international community value of $0.59 \pm 0.21 \mathrm{nmol} \mathrm{L}^{-1}$. DAl was determined using a batch method adapted from Hydes and Liss (1976).

Supporting oceanographic data were provided by workers from the Royal Netherlands Institute for Sea Research (NIOZ), and these included underway and conductivitytemperature-depth (CTD) physical data, dissolved oxygen, and nutrient data. Dissolved oxygen was determined using Winkler titrations, and nitrate and phosphate were determined using segmented flow analysis (Grashoff et al. 1983). Turbidity was measured using a precalibrated Seapoint Turbidity Meter (Seapoint Sensors) mounted on the CTD frame and data reported as FTU (Formazine turbidity units). Photosynthetically active radiation (PAR) was determined using an irradiance sensor (4410, Royal NIOZ). All contour plots were formulated using Ocean Data View (Schlitzer 2007).

\section{Results and discussion}

Vertical distribution of dissolved iron redox species near the shelf slope-The physico-chemical data for the vertical 


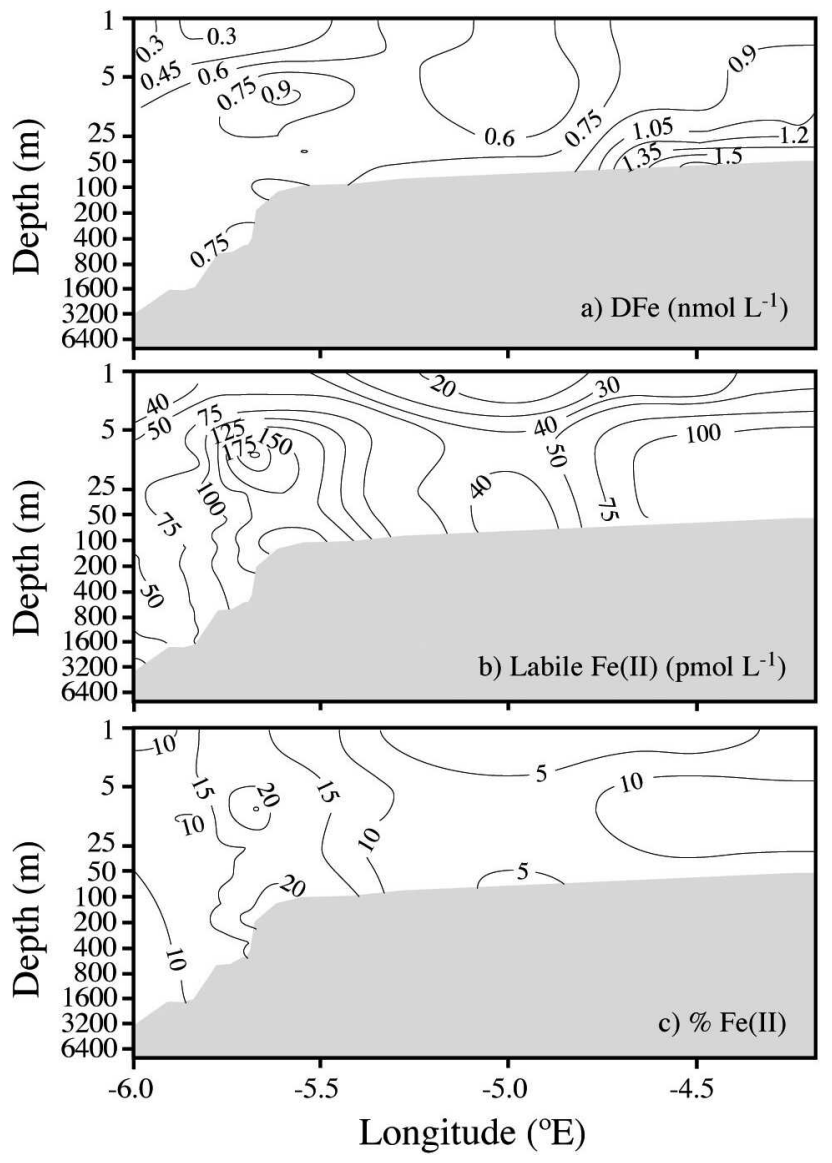

Fig 4. A comparison of concentrations of (a) DFe with (b) labile $\mathrm{Fe}(\mathrm{II})$, and (c) \% Fe(II) distribution over the European continental shelf and slope.

section over the slope of the European continental margin are shown in Fig. 3. Salinities in the surface mixed layer $(<100 \mathrm{~m})$ showed a horizontal gradient from French coastal waters (salinity $=35.15$ ) to the off-shelf waters (salinity $=35.6$ ). Dissolved oxygen ranged between 200 and $280 \mu \mathrm{mol} \mathrm{L}-1$ in the near-surface waters $(<500 \mathrm{~m})$, indicating oxic conditions. An oxygen minimum of $183 \mu \mathrm{mol}$ $\mathrm{L}^{-1}$ was observed at $800-\mathrm{m}$ depth, which was attributed to Mediterranean Outflow Water. Nitrate concentrations were close to uniform in the near-surface waters (5.5$7 \mu \mathrm{mol} \mathrm{L}-1,5-200-\mathrm{m}$ depth) and increased with depth to a maximum of $22.7 \mu \mathrm{mol} \mathrm{L} \mathrm{L}^{-1}$ at $\sim 4,000 \mathrm{~m}$. Turbidity maxima ( $>0.5$ FTU) were found in near-bottom waters near the coast $\left(4.1-4.6^{\circ} \mathrm{W}\right)$ and attributed to sediment resuspension. An isolated surface-water patch of high turbidity was observed above the shelf break $\left(5.7^{\circ} \mathrm{W}\right)$, which may have been either horizontally transported benthic material, an active bloom, or remnants of an earlier bloom. It was not possible to determine the nature of this patch because no discrete chlorophyll or flow cytometry data were available for the cruise.

Density data in surface waters showed a decrease away from the coast to the open ocean $\left(\sigma_{\theta} 26.9-28.0 \mathrm{~kg} \mathrm{~m}^{-3}\right)$, corresponding to an increase in temperature $\left(10.5-12.0^{\circ} \mathrm{C}\right)$.
The horizontal density gradient was greatest beyond the shelf break $\left(\sim 6^{\circ} \mathrm{W}\right)$, and vertical density profiles indicated that the depths of the benthic boundary layer (BBL) varied between 10 and $60 \mathrm{~m}$ (Laës et al. 2006) on the shelf.

The vertical distribution of DFe over the shelf and slope (Fig. 4) showed a DFe gradient between off-shelf surface waters $\left(0.15-0.5 \mathrm{nmol} \mathrm{L}^{-1}\right)$ and near-bottom coastal waters $\left(0.8-2.1 \mathrm{nmol} \mathrm{L}^{-1}\right)$. These values compared well with the results of Laës et al. (2006), which showed concentrations of $\sim 0.45 \mathrm{nmol} \mathrm{L} ~^{-1}$ in offshore surface waters and $0.9-2.4 \mathrm{nmol} \mathrm{\textrm {L } ^ { - 1 }}$ for shelf waters. These authors reported enhanced DFe concentrations $(>0.8 \mathrm{nmol} \mathrm{L}-1)$ on the shelf break and in regions of maximum turbidity. It was concluded that in the coastal waters, enhanced DFe concentrations were the result of sediment resuspension. DFe-enriched near-bottom waters (0.6-2.0 nmol L-1) were also found in waters of high turbidity $(500-1,000 \mathrm{~m})$ associated with the highest total dissolvable $\mathrm{Fe}$ (TDFe) concentration observed over the upper slope, where high flow velocities, bioturbation, and anoxic bacterial mineralization have been reported (Heip et al. 2001). This feature was attributed both to high iron dissolution fluxes from pore waters and to resuspension of particulate iron induced by internal wave activity

The results from our study show that labile Fe(II) concentrations were enriched on the continental slope and were near or below the detection limit of the FI-CL method $\left(<12-50 \mathrm{pmol} \mathrm{L}{ }^{-1}\right)$ in the off-shelf waters $\left(6-8^{\circ} \mathrm{W}\right)$. The concentrations on the upper slope were found to increase significantly near the shelf break and in the coastal waters, where near-bottom concentrations reached maxima of 280 pmol L ${ }^{-1}\left(5.7^{\circ} \mathrm{W}, 10-\mathrm{m}\right.$ depth) and $180 \mathrm{pmol} \mathrm{L}^{-1}$ $\left(5.6^{\circ} \mathrm{W}, 190-\mathrm{m}\right.$ depth), respectively. Figure 4 shows a comparison of the labile $\mathrm{Fe}(\mathrm{II})$ and $\% \mathrm{Fe}(\mathrm{II})$ with the $\mathrm{DFe}$ distribution in the slope and surface shelf waters. The observed distribution is evidence that several mechanisms were controlling iron speciation in these waters. Firstly, enhanced concentrations $\left(>100 \mathrm{pmol} \mathrm{L}^{-1}\right)$ were found in coastal bottom waters near the turbidity maximum, presumably due to the release of labile $\mathrm{Fe}(\mathrm{II})$ following resuspension of surface sediments. In contrast, the enhanced concentrations in the less turbid near-bottom waters on the shelf break (100-280 pmol L ${ }^{-1}$ and $>15$ $\% \mathrm{Fe}[\mathrm{II}])$ were more indicative of diffusion from underlying sediments. Finally, the elevated turbidity and high labile $\mathrm{Fe}(\mathrm{II})\left(>150 \mathrm{pmol} \mathrm{L}^{-1}\right)$ and $\mathrm{DFe}$ concentrations found between 5 - and 50-m depth on the shelf break suggest that a patch of lithogenic or biological particles (e.g., a degrading bloom) produced significant concentrations of labile dissolved iron species.

In contrast, the deep-water samples taken within $50 \mathrm{~m}$ of the seafloor in the abyssal plain of the Bay of Biscay $\left(46.0^{\circ} \mathrm{N}, 8.0^{\circ} \mathrm{W}\right.$ to $\left.46.6^{\circ} \mathrm{N}, 6.4^{\circ} \mathrm{W}\right)$ showed no clear enrichment of labile Fe(II) or DFe (Figs. 4 and 5). This was considered to be a result of (1) highly efficient mineralization of sinking organic particles in the intermediate waters near the slope, (2) low turbidity and bottom sediment resuspension (turbidity $<0.1 \mathrm{FSU}$ ), and (3) more refractory sediments and deep oxygen penetration in the abyssal plain. 
In order to estimate a rate for labile $\mathrm{Fe}(\mathrm{II})$ production in the near-bottom waters of the shelf region, it was assumed that labile $\mathrm{Fe}(\mathrm{II})$ concentrations determined in the benthic boundary layer were representative of a $1-\mathrm{m}^{2}$ column of water at each station, and that diffusion away from the benthic boundary layers was negligible. Therefore, if the interactions between the overlying water and sediments were at a pseudo-steady state, the following rate equation equates to zero:

$$
d[\mathrm{Fe}(\mathrm{II})] / d t=\mathrm{k}_{\text {sediments }}-\mathrm{k}_{\mathrm{ox}}[\mathrm{Fe}(\mathrm{II})]
$$

where $\mathrm{k}_{\text {sediments }}$ is the zero-order rate constant for the input of $\mathrm{Fe}(\mathrm{II})$ from sediments, and $\mathrm{k}_{\mathrm{ox}}$ is the oxidation rate constant. A zero-order rate constant is appropriate for this calculation because DFe concentrations in benthic flux chambers have been reported to vary linearly with time ( $r^{2}$ $=>0.7$ for $77 \%$ of observations; Elrod et al. 2004). To calculate $\mathrm{k}_{\mathrm{ox}}$ with the temperature-dependant oxidation kinetics of Millero and Sotolongo (1989) and Millero et al. (1987), the mean temperature, salinity, Fe(II) concentration, and oxygen concentrations in the BBL were used (11.1 ${ }^{\circ} \mathrm{C}, 35.4,94 \mathrm{pmol} \mathrm{L}-1,256 \mu \mathrm{mol} \mathrm{L}-1$, respectively), and the hydrogen peroxide concentration and $\mathrm{pH}$ were assumed to be $5 \mathrm{nmol} \mathrm{L}^{-1}$ and 8.0, respectively. The calculated $\mathrm{k}_{\mathrm{ox}}$ value for these conditions was $0.055 \mathrm{~min}^{-1}$. The model results for the flux of $\mathrm{Fe}(\mathrm{II})$ from the bottom sediments gave a rate of $73-370 \mu \mathrm{mol} \mathrm{m} \mathrm{m}^{-2} \mathrm{~d}^{-1}$ within a BBL of $10-50 \mathrm{~m}$ (Laës et al. 2006). This rate is consistent with fluxes reported for the Aquitaine margin (41$140 \mu \mathrm{mol} \mathrm{m}^{-2} \mathrm{~d}^{-1}$; Hyacinthe et al. 2001), and it is higher than those reported for the Californian shelf $(0.5-15 \mu \mathrm{mol}$ $\mathrm{m}^{-2} \mathrm{~d}^{-1}$; Elrod et al. 2004).

Recently, Hopkinson and Barbeau (2007) determined iron redox speciation using FI-CL for the oxic and suboxic waters of the tropical Northeast Pacific $(100-1,300 \mathrm{~km}$ offshore). These workers observed Fe(II) concentrations of $120-150 \mathrm{pmol} \mathrm{L}^{-1}(21-24 \%$ of total dissolved iron) in the suboxic zone (dissolved oxygen $<5 \mu \mathrm{mol} \mathrm{L}^{-1}$ ) of the upper water column (0-300 m). It was concluded that the elevated $\mathrm{Fe}$ (II) concentrations observed were a result of in situ redox processes rather than advection of pore waters from reducing sediments. The data reported here for near-bottom shelf waters $(5-30 \% \mathrm{Fe}[\mathrm{II}])$ show a similar range as the data reported by Hopkinson and Barbeau (2007), and both sets of observations indicate higher $\mathrm{Fe}(\mathrm{II})$ values than would be predicted by equilibrium calculations for inorganic iron species. However, the labile $\mathrm{Fe}(\mathrm{II})$ distribution reported here shows detectable concentrations $>100 \mathrm{~m}$ away from sediment sources and the turbidity maxima. Considering the short half-life of inorganic $\mathrm{Fe}(\mathrm{II})$ in these cool oxic waters (2-40 $\mathrm{min}$ ), we hypothesize that Fe(II) species were stabilized by complexation or the release of reducing species (e.g., thiols) from the sediments. This hypothesis is supported by the observations of significant changes in Fe(II) oxidation rates in the presence of organic molecules (e.g., SantanaCasiano et al. 2006 and references therein).

Horizontal distribution of dissolved iron and aluminium in European continental-shelf surface waters-DFe, DAl, and
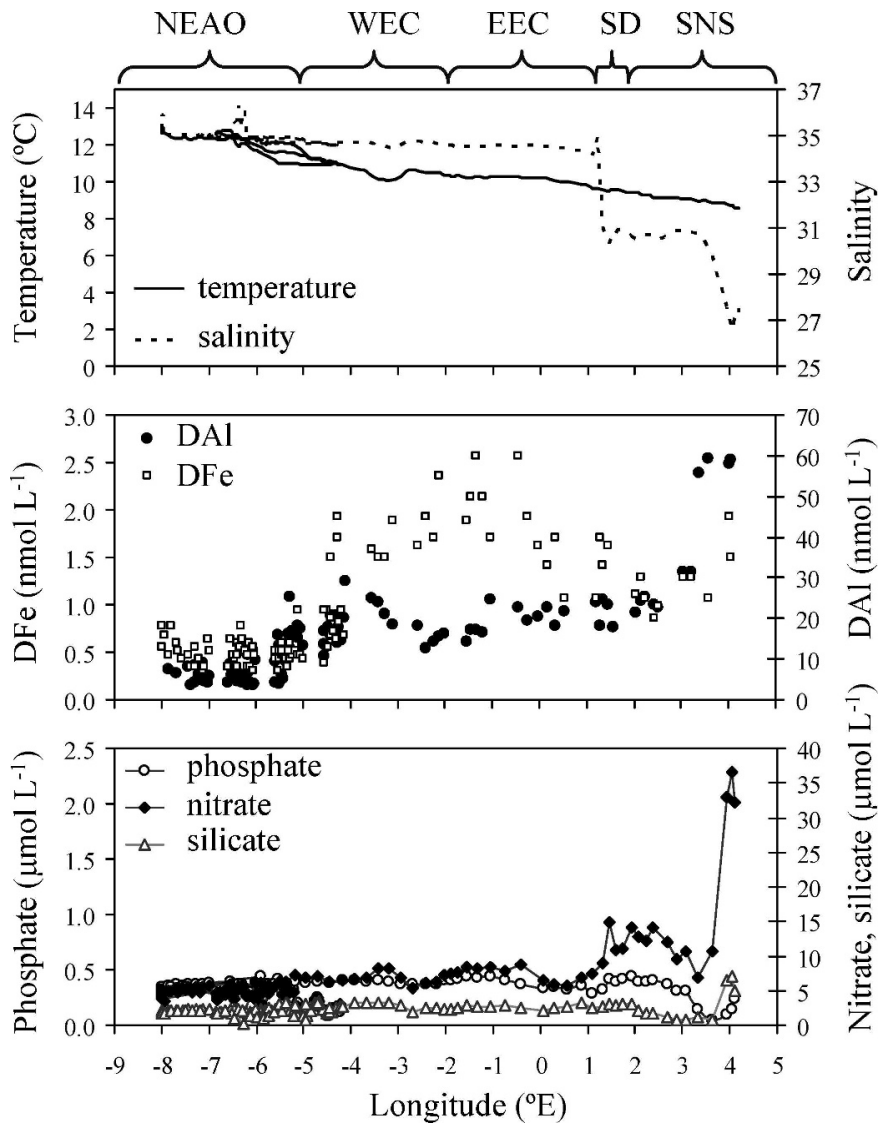

Fig 5. Variation in surface DFe, DAl, and macronutrient concentrations over a transect between the Northeast Atlantic Ocean $\left(46.0^{\circ} \mathrm{N}, 8.0^{\circ} \mathrm{W}\right)$ and the coast of the Netherlands $\left(52.4^{\circ} \mathrm{N}\right.$, $\left.4.2^{\circ} \mathrm{E}\right)$. Provinces are defined as the northeast Atlantic Ocean (NEAO), the western English Channel (WEC), the eastern English Channel (EEC), the Strait of Dover (SD), and the southern North Sea (SNS).

dissolved nutrient distributions in the surface waters (2-4$\mathrm{m}$ depth) were determined for a transect (positions A to C in Fig. 1) from the northeast Atlantic Ocean $\left(46.0^{\circ} \mathrm{N}\right.$, $\left.8.0^{\circ} \mathrm{W}\right)$ to the coast of the Netherlands $\left(52.4^{\circ} \mathrm{N}, 4.2^{\circ} \mathrm{E}\right)$ (Fig. 5). Well-defined salinity gradients were observed between the North Atlantic Ocean and the shelf waters (34.5-36) and between the English Channel and the coastal waters of the North Sea (27-34.5). Monthly averaged surface chlorophyll $a$ from the SeaWiFS satellite data ranged between $\sim 2.5$ and $4 \mathrm{mg} \mathrm{m}^{-3}$ in the English Channel and southern North Sea at the time of our study, confirming that spring phytoplankton growth had commenced. Dissolved nitrate, phosphate, and silicate concentrations in the surface waters were in the ranges $0.5-37.0$, $0.01-0.50$, and $0.5-7.0 \mu \mathrm{mol} \mathrm{L}-1$, respectively. The lowest phosphate and silicate concentrations were found at $3.5^{\circ} \mathrm{E}$ in the southern North Sea and indicated significant drawdown in this region.

The lowest DFe and DAl surface-water concentrations were found in the northeast Atlantic Ocean and on the slope, where they varied from 0.14 to $0.6 \mathrm{nmol} \mathrm{L}^{-1}$ and 7 to $22 \mathrm{nmol} \mathrm{L}^{-1}$, respectively. In the English Channel, the concentrations of both elements were higher, ranging from 

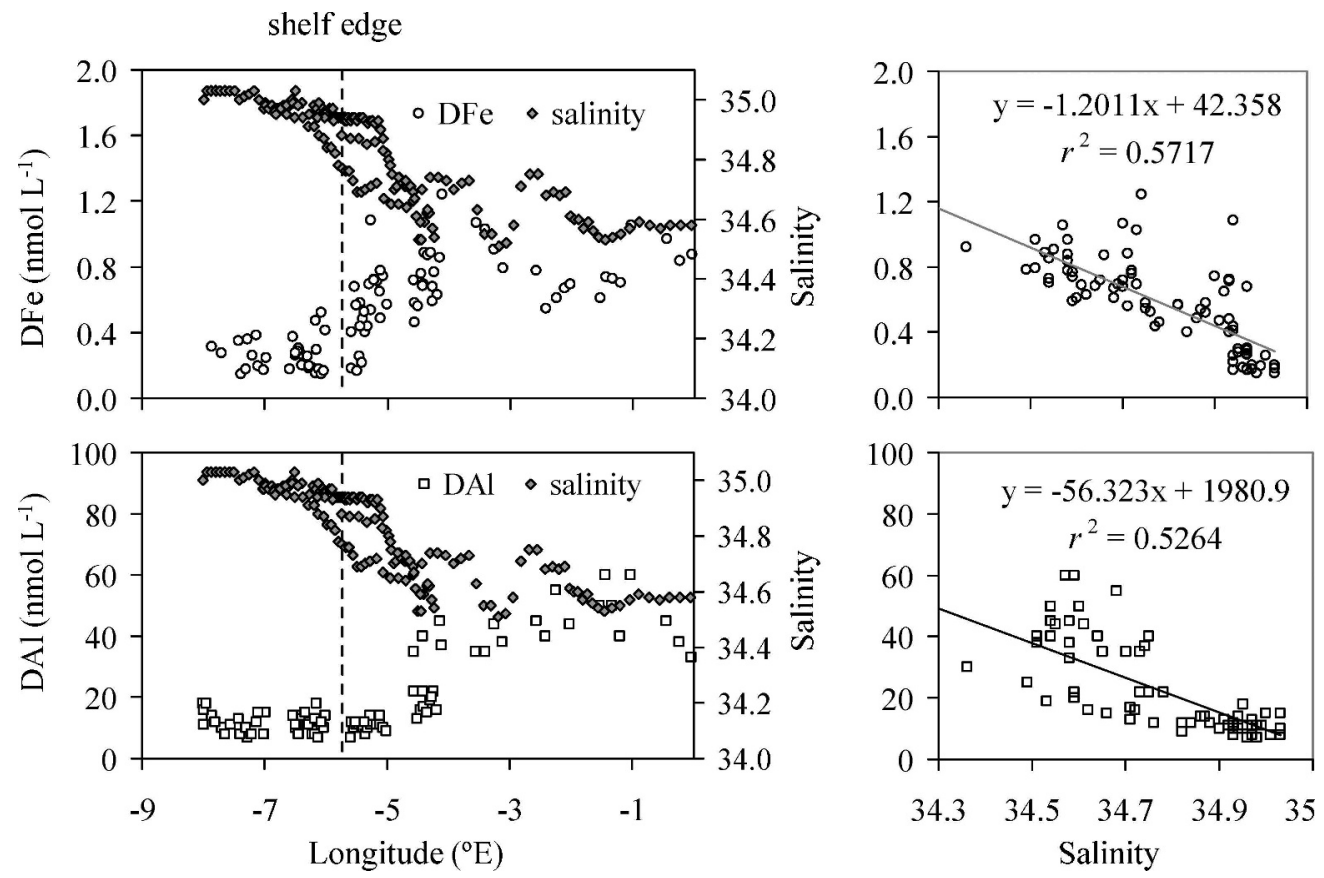

Fig 6. The variation of DFe and DAl concentrations with salinity in the English Channel and open-ocean surface waters.

0.5 to $1.25 \mathrm{nmol} \mathrm{L}^{-1}$ for DFe and 25 to $60 \mathrm{nmol} \mathrm{L}^{-1}$ for DAl. The DAl concentrations compare well with springtime concentrations previously reported for the English Channel $\left(26.0 \pm 9.8 \mathrm{nmol} \mathrm{L}^{-1}\right.$; Hydes 1989). DFe was consistently lower than the surface-water data reported for the same region in March 1998 (Boye et al. 2003), when North Atlantic and English Channel surface waters were $0.6-0.9$ and $1.0-1.7 \mathrm{nmol} \mathrm{L}^{-1}$, respectively. This difference represents either intermethod differences and/or interannual variation of water mass mixing and the onset of the spring bloom.

The four- to fivefold decrease in $\mathrm{DFe}$ and $\mathrm{DAl}$ concentrations found between shelf and open-ocean waters was similar to the one- to fivefold decrease seen for $\mathrm{Cd}, \mathrm{Ni}$, $\mathrm{Cu}$, and $\mathrm{Mn}$ in previous studies of the European continental shelf (Le Gall et al. 1999). Potential iron sources to surface shelf waters include benthic, riverine, and atmospheric inputs. However, along the salinity gradient of 34-35.5, DFe and DAl concentrations in the English Channel were predominantly controlled by mixing between open-ocean and the less-saline shelf waters. Figure 6 shows the surface-water DFe, DAl, and salinity data over the slope of the European continental margin. Plots of DFe and DAl concentrations versus salinity showed nearconservative mixing $\left(r^{2}=0.572\right.$ and 0.528 , respectively; $n$ $=92, p<0.001)$ of the dissolved metals between the English Channel and the open ocean. The DFe and DAl concentration gradient occurred over a relatively short distance $(<200 \mathrm{~km})$, and this supports the conclusion of Hydes et al. (2001) that minimal large-scale horizontal transport of water across the shelf break occurs in this region despite severe winter storms.

In comparison, the full $\mathrm{DFe}$ and $\mathrm{DAl}$ data sets $\left(8.0^{\circ} \mathrm{W}-\right.$ $4.2^{\circ} \mathrm{E}$ ), which included eastern English Channel and North
Sea waters, were not well correlated with salinity $\left(r^{2}<0.3\right.$, $n=109$ ). Hence, DFe and DAl distributions were nonconservative and were more influenced by partitioning between particulate matter and the dissolved phase. Furthermore, there was a lack of covariance between DFe and DAl distributions in the eastern English Channel and the southern North Sea $\left(0-4^{\circ} \mathrm{E}\right)$. DAl decreased to nearly half the concentration found in the middle of the Channel (20-40 nmol L $\left.{ }^{-1}\right)$, following a similar trend to silicate, consistent with the seasonal depletion of DAl in the North Sea due to seasonal biological scavenging (Van Beusekom 1988). In contrast, DFe concentrations continued to increase eastward through the southern North Sea $\left(1.5-4^{\circ} \mathrm{E}\right)$ as the water-column depth became more shallow.

Dissolved iron redox speciation in European continentalshelf surface waters-The results from the surface transect $\left(46.0^{\circ} \mathrm{N}, 8.0^{\circ} \mathrm{W}\right.$ to $52.4^{\circ} \mathrm{N}, 4.2^{\circ} \mathrm{E}$, A to $\mathrm{C}$ in Fig. 1$)$ show that surface-water concentrations of $\mathrm{Fe}(\mathrm{II})$ increased simultaneously with DFe over the shelf from the Northeast Atlantic into the shelf waters of the English Channel $(<26$ to $12-75 \mathrm{pmol} \mathrm{L}^{-1}$; Fig. 7). The labile Fe(II) surface data showed high variability, and labile $\mathrm{Fe}(\mathrm{II})$ was found to form an important part of the DFe pool throughout the transect (mean of $5.0 \pm 2.7 \%, n=92$ ). No significant correlation was observed between solar radiation and the labile $\mathrm{Fe}(\mathrm{II})$ : DFe ratio for the transect west of the Strait of Dover $\left(2^{\circ} \mathrm{E}-4.2^{\circ} \mathrm{W}\right)$ or in the surface waters off the shelf $\left(r^{2}\right.$ $<0.4)$. However, labile Fe(II) concentrations showed a diurnal trend in the low-salinity waters of the Scheldt river plume, between $1.5^{\circ} \mathrm{E}$ and $3.4^{\circ} \mathrm{E}$, where no significant changes in $\mathrm{DFe}$ or salinity occurred but elevated concentrations of labile $\mathrm{Fe}(\mathrm{II})$ were observed $\left(>100 \mathrm{pmol} \mathrm{L}^{-1}\right)$. The most probable cause of this increase was direct and/or 


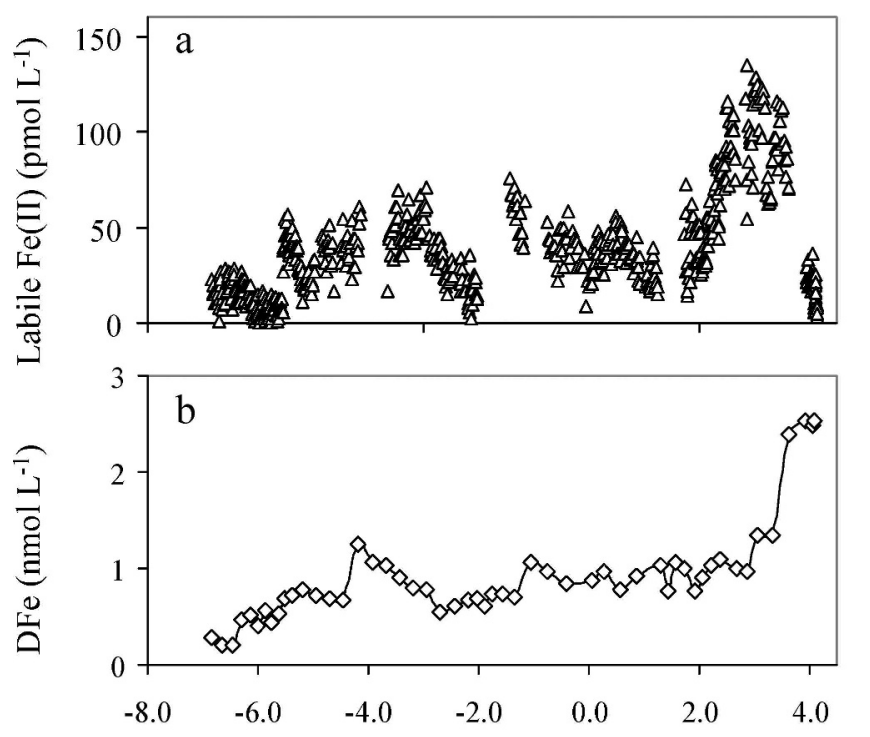

Longitude $\left({ }^{\circ} \mathrm{E}\right)$

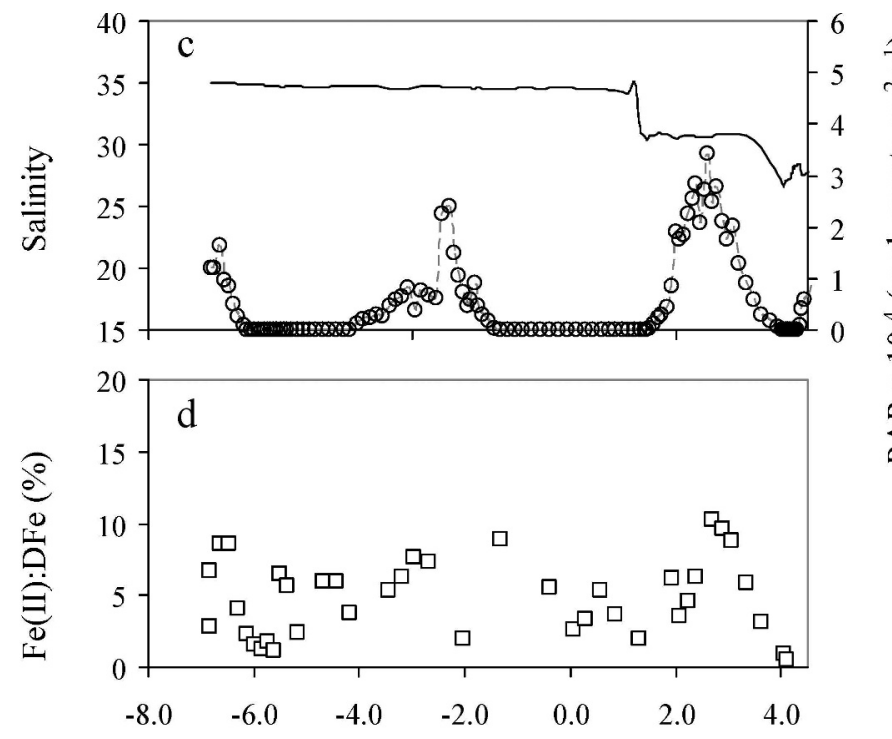

Longitude $\left({ }^{\circ} \mathrm{E}\right)$

Fig 7. Iron redox speciation (a,b,d), salinity (indicated by a line in panel c), and photosynthetic active radiation (PAR) (indicated by circles in panel c) in the European continental-shelf surface waters.

indirect photochemical reduction of $\mathrm{Fe}(\mathrm{III})$ species facilitated by high concentrations of dissolved and colloidal organic matter delivered by the river plume.

To estimate the photoreduction rate in these waters, a steady-state redox speciation model was used (Sunda 2001). If it is assumed that all the labile Fe(II) determined between $2.0^{\circ} \mathrm{E}$ and $3.5^{\circ} \mathrm{E}$ was dissociated inorganic $\mathrm{Fe}(\mathrm{II})$ due to photoreduction reactions and that the difference between $\mathrm{DFe}$ and labile $\mathrm{Fe}(\mathrm{II})$ represented complexed dissolved iron $(\mathrm{Fe}[\mathrm{III}] \mathrm{L})$ rather than inorganic and particulate species $(>0.2 \mu \mathrm{m})$, then a simple rate expression can be used to describe the system:

$$
\mathrm{k}_{\mathrm{hv} \text { cond }}=\mathrm{k}_{\mathrm{ox}}\left[\mathrm{Fe}(\mathrm{II})^{\prime}\right] /[\mathrm{Fe}(\mathrm{III}) \mathrm{L}]
$$

where $\mathrm{L}$ is an organic ligand, and $\mathrm{k}_{\mathrm{hv}}$ cond and $\mathrm{k}_{\mathrm{ox}}$ are the conditional first-order photoreduction rate constants at the midday solar maximum and calculated oxidation rate constant, respectively.

Using temperature-dependant oxidation kinetics (Millero et al. 1987; Millero and Sotolongo 1989), $\mathrm{k}_{\mathrm{ox}}$ for the English Channel waters in March 2002 was calculated to be $0.17 \mathrm{~s}^{-1}$ (temperature $=9.3^{\circ} \mathrm{C}$, salinity $=30.56$, dissolved oxygen $=260 \mu \mathrm{mol} \mathrm{L}-1$, estimated $\mathrm{H}_{2} \mathrm{O}_{2}=50 \mathrm{nmol} \mathrm{L}^{-1}$, $\mathrm{pH}=8.0)$. Hence, in these waters, $\mathrm{Fe}(\mathrm{II})$ had a half-life of 4 min. If a steady-state $\mathrm{Fe}(\mathrm{II})$ concentration of $100 \mathrm{pmol}$ $\mathrm{L}^{-1}$ is used in the model, along with a DFe concentration of $1.10 \mathrm{nmol} \mathrm{L}-1$ (midday concentrations found at $2.5^{\circ} \mathrm{E}$ ), then the upper limit for the conditional first-order photoreduction rate constant ( $\mathrm{k}_{\mathrm{hv}}$ cond $)$ is $0.02 \mathrm{~s}^{-1}$. If the calculated value is extrapolated to estimate photoreduction of dissolved iron in the open-ocean surface waters off the shelf (where $\mathrm{DFe}=0.3 \mathrm{nmol} \mathrm{L}^{-1}$, temperature $=12.2^{\circ} \mathrm{C}$, salinity $=35$, dissolved oxygen $=260 \mu \mathrm{mol} \mathrm{L}^{-1}$, estimated $\mathrm{H}_{2} \mathrm{O}_{2}=50 \mathrm{nmol} \mathrm{L}-1, \mathrm{pH}=8.0$ ), maximum steady-state concentrations of $25 \mathrm{pmol} \mathrm{L}^{-1}$ would be predicted for this time of year. This was close to the detection limit of the FICL method (5-12 $\mathrm{pmol} \mathrm{L}^{-1}$ ) and the scatter of the data, and, thus, together with the lower PAR values seen in these waters (see Fig. 7), it explains why no clear diurnal trends in the labile $\mathrm{Fe}(\mathrm{II})$ data were observed in these waters.

The estimated $\mathrm{k}_{\mathrm{hv} \text { cond }}$ value was two orders of magnitude higher than previously reported first-order photoreduction constants for colloidal iron in open-ocean waters (e.g., $2.3 \times$ $10^{-4} \mathrm{~s}^{-1}$; Johnson et al. 1994) and for dissolved iron in coastal seawater (e.g., $6.3 \times 10^{-4} \mathrm{~s}^{-1}$; Miller et al. 1995). Such a variation is to be expected due to the exclusion of particulate iron from the model calculations, as well as variation in organic speciation, light regimes, and the kinetic model used. It also shows that further work is required to better constrain the kinetic constants of Fe photoreduction reactions in seawater under ambient conditions.

Overall, the labile Fe(II) data in European continentalshelf waters were consistent with strong Fe fluxes from shelf redox processes caused by reducing benthic environments, resuspension, and photoreduction. However, advective and diffusive transport was not considered in the calculations and the existence of detectable labile Fe(II) concentrations $>100 \mathrm{~m}$ from the apparent sources would suggest longer half-lives than would be predicted for the majority of known iron complexes. Hence, further studies are required to characterize the redox properties of iron complexes in shelf regions.

\section{References}

Bowie, A. R., E. P. Achterberg, P. L. Croot, H. J. W. De BaAr, P. LaAn, J. W. Moffett, S. Ussher, and P. J. Worsfold. 2006. A community-wide intercomparison exercise for the determination of dissolved iron in seawater. Mar. Chem. 98: 81-99. 
E. P. Achterberg, R. F. C. Mantoura, and P. J. WORSFOLD. 1998. Determination of sub-nanomolar levels of iron in seawater using flow injection with chemiluminescence detection. Anal. Chim. Acta 361: 189-200.

, P. N. Sedwick, S. Ussher, and P. J. Worsfold. 2002. Real-time monitoring of picomolar concentrations of iron(II) in marine waters using automated flow injectionchemiluminescence instrumentation. Envir. Sci. Tech. 36: 4600-4607.

Boyd, P. W. AND OTHERs. 2007. Mesoscale iron enrichment experiments 1993-2005: Synthesis and future directions. Science 315: 612-617.

Boye, M., A. P. Aldrich, C. M. G. Van Den Berg, J. T. M. De Jong, M. Veldhuis, and H. J. W. De BaAr. 2003. Horizontal gradient of the chemical speciation of iron in surface waters of the northeast Atlantic Ocean. Mar. Chem. 80: 129-143.

Croot, P. L., AND P. LAAN. 2002. Continuous shipboard determination of $\mathrm{Fe}(\mathrm{II})$ in polar waters using flow injection analysis with chemiluminescence detection. Anal. Chim. Acta 466: $261-273$.

- AND OTHERS. 2005. Spatial and temporal distribution of $\mathrm{Fe}(\mathrm{II})$ and $\mathrm{H}_{2} \mathrm{O}_{2}$ during EisenEx, an open ocean mesoscale iron enrichment. Mar. Chem. 95: 65-88.

De Jong, J. T. M., J. Den Das, U. Bathmann, M. H. C. Stoll, G. Kattner, R. F. Nolting, and H. J. W. De BaAr. 1998. Dissolved iron at subnanomolar levels in the Southern Ocean as determined by ship-board analysis. Anal. Chim. Acta 377: 113-124.

Dhungana, S., And A. L. CRumbliss. 2005. Coordination chemistry and redox processes in siderophore-mediated iron transport. Geomicrobiol. J. 22: 87-98.

Elrod, V. A., W. M. Berelson, K. H. Coale, and K. S. Johnson. 2004. The flux of iron from continental shelf sediments: A missing source for global budgets. Geophysical Research Letters 31: L12307, doi:10.1029/2004GL020216.

Falkowski, P. G., R. T. Barber, and V. Smetacek. 1998. Biogeochemical controls and feedbacks on ocean primary production. Science 281: 200-206.

Grashoff, K., M. Erhardt, and K. Kremling. 1983. Methods in seawater analyses., Wiley-VCH.

Heip, C. H. R. AND others. 2001. The role of the benthic biota in sedimentary metabolism and sediment-water exchange processes in the Goban Spur area (NE Atlantic). Deep-Sea Res. Pt II 48: 3223-3243.

Hopkinson, B. M., and K. A. Barbeau. In press. Organic and redox speciation of iron in the eastern tropical North Pacific suboxic zone. Mar. Chem. doi:10.1016/j.marchem.2006.02.008.

Hudson, R. J. M., And F. M. M. Morel. 1990. Iron transport in marine-phytoplankton-kinetics of cellular and medium coordination reactions. Limnol. Oceanogr. 35: 1002-1020.

Huthnance, J. M., H. Coelho, C. R. Griffiths, P. J. Knight, A. P. Rees, B. Sinha, A. Vangriesheim, M. White, and P. G. Chatwin. 2001. Physical structures, advection and mixing in the region of Goban spur. Deep-Sea Res. Pt II 48: 2979-3021.

Hyacinthe, C., P. Anschutz, P. Carbonel, J. M. Jouanneau, and F. J. Jorissen. 2001. Early diagenetic processes in the muddy sediments of the Bay of Biscay. Mar. Geol. 177: 111-128.

Hydes, D. J. 1989. Seasonal-variation in dissolved aluminum concentrations in coastal waters and biological limitation of the export of the riverine input of aluminum to the deep-sea. Cont. Shelf Res. 9: 919-929.

- AND OTHERs. 2001. Supply and demand of nutrients and dissolved organic matter at and across the NW European shelf break in relation to hydrography and biogeochemical activity. Deep-Sea Res. Pt II 48: 3023-3047.
—, AND P. S. Liss. 1976. Fluorimetric method for determination of low concentrations of dissolved aluminum in natural-waters. Analyst 101: 922-931.

Johnson, K. S., K. H. Coale, V. A. Elrod, and N. W. Tindale. 1994. Iron photochemistry in seawater from the equatorial Pacific. Mar. Chem. 46: 319-334.

—, AND OTHERS. 2003. Surface ocean-lower atmosphere interactions in the Northeast Pacific Ocean Gyre: Aerosols, iron, and the ecosystem response. Global Biogeochem. Cycles 17: 1063, doi:10.1029/2002GB002004.

Laës, A., S. Blain, P. Laan, E. P. Achterberg, G. Sarthou, and H. J. W. DE BAAR. 2003. Deep dissolved iron profiles in the eastern North Atlantic in relation to water masses. Geophys. Res. Letters 30: 1902, doi:10.1029/2003GL017902.

S. J. UsSher, E. P. ACHTERBERG, P. Treguer, and H. J. W. De BaAr. 2006. Sources and transport of dissolved iron and manganese along the continental margin of the Bay of Biscay. Biogeosci. Disc. 3: 1499-1527.

Lam, P. J., J. K. B. Bishop, C. C. Henning, M. A. Marcus, G. A. WAYchunas, AND I. Y. FunG. 2006. Wintertime phytoplankton bloom in the subarctic Pacific supported by continental margin iron. Global Biogeochem. Cycles 20: GB1006, doi:10.1029/2005GB002557.

Le Gall, A. C., P. J. Statham, N. H. Morley, D. J. Hydes, and C. H. Hunt. 1999. Processes influencing distributions and concentrations of $\mathrm{Cd}, \mathrm{Cu}, \mathrm{Mn}$ and $\mathrm{Ni}$ at the North West European shelf break. Mar. Chem. 68: 97-115.

Maldonado, M. T., R. F. Strzepek, S. Sander, and P. W. Boyd. 2005. Acquisition of iron bound to strong organic complexes, with different $\mathrm{Fe}$ binding groups and photochemical reactivities, by plankton communities in Fe-limited sub-Antarctic waters. Global Biogeochem. Cycles 19: GB4S23, doi:10.1029/ 2005GB002481.

Miller, W. L., D. W. King, J. Lin, and D. R. Kester. 1995. Photochemical redox cycling of iron in coastal seawater. Mar. Chem. 50: 63-77.

Millero, F. J., AND S. Sotolongo. 1989. The oxidation of Fe(II) with $\mathrm{H}_{2} \mathrm{O}_{2}$ in seawater. Geochim. Cosmochim. Acta 53: 1867-1873.

, S. Sotolongo, and M. Izaguirre. 1987. The oxidationkinetics of $\mathrm{Fe}(\mathrm{II})$ in seawater. Geochim. Cosmochim. Acta 51: 793-801.

Moore, C. M., M. M. Mills, A. Milne, R. Langlois, E. P. Achterberg, K. Lochte, R. J. Geider, and J. La Roche. 2006. Iron limits primary productivity during spring bloom development in the central North Atlantic. Global Change Biol. 12: 626-634.

Ozturk, M., P. L. Croot, S. Bertilsson, K. Abrahamsson, B. Karlson, R. David, A. Fransson, and E. Sakshaug. 2004. Iron enrichment and photoreduction of iron under UV and PAR in the presence of hydroxycarboxylic acid: Implications for phytoplankton growth in the Southern Ocean. Deep-Sea Res. Pt II 51: 2841-2856.

Santana-Casiano, J. M., A. Gonzalez-Davila, and F. J. Millero. 2006. The role of Fe(II) species on the oxidation of $\mathrm{Fe}(\mathrm{II})$ in natural waters in the presence of $\mathrm{O}_{2}$ and $\mathrm{H}_{2} \mathrm{O}_{2}$. Mar. Chem. 99: 70-82.

Sarthou, G. And others. 2003. Atmospheric iron deposition and sea-surface dissolved iron concentrations in the eastern Atlantic Ocean. Deep-Sea Res. Pt I 50: 1339-1352.

Schlitzer, R. 2007. Ocean Data View [Internet]. Available from http://odv.awi.de/home.html, Alfred Wegener Institute, Bremerhaven, obtained July 2007.

Sunda, W. G. 2001. Bioavailability and bioaccumulation of iron in the sea, p. 41-84. In K. A. H. D. R. Turner [ed.], The biogeochemistry of iron in seawater. IUPAC Series on Analytical and Physical Chemistry of Environmental Systems. Wiley. 
Ussher, S. J., M. Yaqoob, E. P. Achterberg, A. Nabi, and P. J. WorsFold. 2005. Effect of model ligands on iron redox speciation in natural waters using flow injection with luminol chemiluminescence detection. Anal. Chem. 77: 1971-1978.

Van Beusekom, J. E. E. 1988. Distribution of dissolved aluminium in the North Sea: Influence of biological processes. Mitteil. Geol.-Palaeontol. Inst. Univ. Hamburg 65: 137-151.

Van Den Berg, C. M. G. 1995. Evidence for organic complexation of iron in seawater. Mar. Chem. 50: 139-157.
Waite, T. D. 2001. Thermodynamics of the iron system in seawater, p. 291-342. In K. A. H. D. R. Turner [ed.], The biogeochemistry of iron in seawater. IUPAC Series on Analytical and Physical Chemistry of Environmental Systems. Wiley.

Received: 27 July 2006 Amended: 30 May 2007 Accepted: 19 June 2007 